\title{
Hubungan Tingkat Pengetahuan Tentang Alat KB dengan Pemakaian Kontrasepsi Modern pada Wanita Remaja Kawin di Pulau Jawa (Analisis SDKI 2017)
}

\author{
Relationship between Knowledge of Contraceptive Methods and Modern \\ Contraceptive Use Among Adolescent Married Women In Java Island (Analysis of \\ IDHS 2017)
}

\author{
Priskatindea ${ }^{a^{*}}$, Sudarto Ronoatmodjo ${ }^{\mathrm{b}}$ \\ ${ }^{\text {a }}$ Program Studi Magister Epidemiologi, Fakultas Kesehatan Masyarakat Universitas Indonesia, Depok 16424, Indonesia \\ ${ }^{\text {b }}$ Departemen Epidemiologi, Fakultas Kesehatan Masyarakat Universitas Indonesia, Lantai 1 Gedung A, Kampus UI Depok, Indonesia
}

\section{A B S T R A K}

Prevalensi pemakaian metode KB modern pada wanita kawin usia remaja di Pulau Jawa tahun 2017 tergolong masih rendah, yakni $27,8 \%$. Terbatasnya tingkat pengetahuan remaja mengenai pilihan kontrasepsi adalah salah satu hambatan pemakaian kontrasepsi pada remaja. Penelitian ini memiliki tujuan untuk mengetahui hubungan antara tingkat pengetahuan tentang alat/ cara KB dengan pemakaian kontrasepsi modern pada wanita kawin usia remaja di Pulau Jawa. Penelitian ini menggunakan data sekunder dengan menganalisis hasil dari Survei Demografi dan Kesehatan Indonesia (SDKI) Tahun 2017. Sampel adalah 309 orang wanita berusia 15-19 tahun yang berdomisili di Pulau Jawa dengan status kawin. Pada hasil ditemukan sebanyak 62,4\% responden memakai alat kontrasepsi modern. Berdasarkan Renstra BKKBN 2020-2024 angka ini masih dibawah target capaian modern Contraceptive Prevalence Rate (mCPR) yakni $63,41 \%$. Selain itu diketahui hanya 56,4\% wanita kawin usia remaja yang memiliki tingkat pengetahuan alat/cara KB yang baik (mengetahui setidaknya 7 alat/cara KB). Hasil analisis multivariat menunjukkan bahwa tingkat pengetahuan tentang alat/cara KB tidak mempengaruhi pemakaian kontrasepsi pada wanita kawin usia remaja di Pulau Jawa setelah dikontrol variabel paritas, pendidikan suami, pengambil keputusan KB, dan kepemilikan jaminan kesehatan ( $P R=0,75$; CI 95\% 0,42-1,36). Kuesioner SDKI kurang dapat menggambarkan tingkat pengetahuan mengenai alat/cara KB karena kurang tereskplorenya pertanyaan yang digunakan sehingga hasil ini kemungkinan masih dipengaruhi adanya bias informasi. Studi ini merekomendasikan untuk dilakukan perbaikan pada pengukuran variabel pengetahuan pada survei selanjutnya dengan menggunakan definisi yang lebih spesifik sehingga dapat menggambarkan tingkat pendidikan responden dengan lebih akurat.

Kata kunci: Kontrasepsi, wanita kawin, remaja, pengetahuan

\section{A B S T R A C T}

Prevalence of modern contraceptive use among adolescent married women in Java Island remains low, namely $27,8 \%$ in 2017. The limited knowledge about contraceptive choices is one of the barriers to contraceptive use in adolescent. The purpose of this study is to identify the relationship between knowledge of contraceptive methods and modern contraceptive use among adolescent married women in Java Island. This study analyzed secondary data of the 2017 Indonesia Demographic and Health Survey (IDHS).We used 309 samples consisting all 15-19 year's old women who currently married and live in Java Island in the survey. The results found that $62.4 \%$ of respondents used modern contraceptives. Based on the BKKBN Strategic Plan for 2020-2024, this results still below the target of the modern Contraceptive Prevalence Rate ( $m C P R$ ), namely 63.41\%. In addition, it is known that only $56.4 \%$ of adolescent married women have a good level of knowledge about contraceptive methods (knowing at least 7 methods). Multivariate analysis showed there is no relationship between knowledge of contraceptive methods and modern contraceptive use among adolescent married women in Java Island adjusted by parity, husband's education, decision makers for contraceptive use, and health insurance ownership ( $P R=0,75 ; C I$ $95 \% 0,42-1,36)$. The IDHS questionnaire wasn't able to describe the level of knowledge of contraception methods accurately because the questions used weren't fully explored so this result was probably still influenced by information bias. This study recommends improvements in the measurement of knowledge variables in the next survey by using a more specific definition of knowledge of contraception methods so it can describe the knowledge level of the respondents more accurately.

Key words: Contraceptive, married women, adolescent, knowledge

terpenuhi secara global. ${ }^{1}$ Pada Tahun 2017, diperkirakan 36 juta remaja wanita usia 15-19 tahun sudah menikah atau seksual aktif. Sementara itu lebih dari setengahnya, sekitar 20 juta anak perempuan lainnya tidak menggunakan kontrasepsi, namun sudah

*Korespondensi: Priskatindea. Program Studi Magister Epidemiologi Fakultas Kesehatan Masyarakat Universitas Indonesia. Email: deadddea@gmail.com 
memiliki kebutuhan untuk menggunakan metode kontrasepsi modern. ${ }^{1}$ Riwayat pemakaian kontrasepsi yang rendah dan tidak konsisten pada remaja diketahui merupakan penyebab tingginya risiko kehamilan dini dan terkena penyakit infeksi menular seksual. ${ }^{2}$ WHO mengatakan bahwa peningkatan penggunaan kontrasepsi secara seksual remaja aktif dapat berkontribusi pada pengurangan kehamilan remaja. ${ }^{3}$

Renstra BKKBN Tahun 2020-2024 menyebutkan salah satu isu strategis yang masih menjadi masalah di Indonesia adalah menurunnya angka pemakaian kontrasepsi modern ( $m C P R$ ) menjadi $57,2 \%$ dan rendahnya pengetahuan remaja mengenai kesehatan reproduksi serta persiapan kehidupan berkeluarga. ${ }^{4}$ Berdasarkan Laporan Kinerja BKKBN Tahun 2019, diketahui angka kelahiran pada remaja wanita usia 15-19 tahun sebesar 33 kelahiran per 1000 wanita usia 15-19 tahun. ${ }^{5}$ Remaja wanita seksual aktif lebih mungkin untuk menikah dibandingkan remaja laki-laki. ${ }^{6}$ Wanita kawin usia remaja cenderung memiliki tekanan untuk hamil dan memiliki anak. ${ }^{7}$ Pemakaian kontrasepsi hanya dipertimbangkan setelah anak pertama lahir. ${ }^{7}$ Wanita kawin usia remaja secara keseluruhan juga cenderung tidak patuh untuk menggunakan kontrasepsi modern, dengan angka kegagalan bervariasi sekitar $36-80 \%{ }^{8}$

Berdasarkan data Survei Demografi dan Kesehatan Indonesia (SDKI) 2017, pemakaian metode KB modern pada wanita kawin usia 15-19 tahun sebesar $44 \%$. Metode suntik KB $(33,6 \%)$ dan pil $(7,3 \%)$ merupakan alat/cara KB modern terbanyak yang digunakan wanita kawin usia 15-19 tahun. Hal ini menurun jika dibandingkan dengan data SDKI tahun 2012, tingkat pemakaian metode/cara KB suntik mencapai 37,3\% dan pil sebanyak 8,8\%. Berdasarkan hasil laporan RISKESDAS 2018 diketahui bahwa pada kelompok umur remaja, alat/cara KB yang paling jarang digunakan adalah kondom dan sterilisasi sebanyak $0,2 \%$.

Pengetahuan mengenai kontrasepsi secara umum sangat bervariasi antar populasi, dengan perbedaan mencolok terlihat pada kaum minoritas dan populasi remaja yang kurang memiliki kesadaran dan pengetahuan tentang berbagai metode kontrasepsi. ${ }^{9}$ Berbagai penelitian telah mengevaluasi tingkat pengetahuan tentang metode kontrasepsi pada remaja. Sejumlah populasi remaja di wilayah sub-sahara Afrika diketahui masih memiliki tingkat pengetahuan mengenai alat/cara KB modern yang rendah, terutama di Kota Chad, yakni hanya sekitar 49\% remaja wanita yang mengetahui metode KB modern. ${ }^{10}$ Penelitian lain yang dilakukan oleh Ritter Todd et al di New South Wales, Australia melaporkan bahwa secara keseluruhan tingkat pengetahuan mengenai alat/cara
KB pada remaja masih rendah, yakni 55\%. Penelitian ini juga menyebutkan bahwa hanya sekitar $44 \%$ remaja yang menjawab benar keseluruhan pertanyaan mengenai metode kontrasepsi jangka panjang dan 34\% remaja yang menjawab benar keseluruhan pertanyaan mengenai metode kontrasepsi jangka pendek. ${ }^{11}$ Pada penelitian ini, tingkat pengetahuan diukur dengan menggunakan kuesioner yang mencakup berbagai tipe alat/cara KB, cara kerja, dan efek samping dari setiap metode KB. ${ }^{11}$ Menurut data SDKI Tahun 2017, 96\% remaja wanita mengetahui setidaknya satu alat/cara KB modern, dan $32 \%$ remaja wanita mengetahui setidaknya satu alat/cara KB tradisional. Angka ini menunjukkan hasil yang lebih tinggi jika dibandingkan penelitan lainnya. Pada data SDKI, tingkat pengetahuan tentang alat/cara KB diukur hanya melalui pertanyaan yang sederhana mengenai apakah mereka pernah mengenali jenis-jenis alat/cara KB tersebut.

WHO mengungkapkan terbatasnya pengetahuan remaja tentang kontrasepsi adalah salah satu hambatan utama bagi penggunaan kontrasepsi pada remaja. ${ }^{12}$ Rendahnya pengetahuan remaja tentang kontrasepsi menyebabkan remaja mudah terpengaruh oleh informasi yang tidak benar, berbagai mitos dan informasi lain yang dapat merugikan. ${ }^{13}$ Sebagian besar remaja mengaku mendapatkan pengetahuan mengenai kontrasepsi melalui orang tua, teman atau internet yang merupakan sumber yang rentan untuk memberikan informasi yang tidak lengkap bahkan tidak benar. ${ }^{14}$ Penelitian yang dilakukan oleh Frost et al di Amerika Serikat menemukan bahwa tingkat pengetahuan merupakan salah satu faktor risiko yang penting pada penggunaan dan pemilihan metode kontrasepsi modern pada remaja $(\mathrm{OR}=1,17$; $p$ value $<0,001) .{ }^{15}$ Begitu pula penelitian yang dilakukan oleh Aryanti $\mathrm{H}$ di Lombok Timur menunjukkan bahwa wanita kawin usia dini dengan tingkat pengetahuan tentang alat/cara KB baik lebih mungkin 2,1 kali untuk menggunakan alat kontrasepsi dibandingkan dengan wanita kawin usia dini dengan tingkat pengetahuan tentang alat/cara KB buruk. ${ }^{16}$ Pada kedua penelitian tersebut, tingkat pengetahuan diukur dengan menggunakan kuesioner yang mencakup berbagai tipe alat/cara KB, cara kerja dan efek samping metode KB serta pengetahuan mengenai tempat mendapatkan pelayanan kontrasepsi. ${ }^{16,17}$

Berdasarkan proyeksi jumlah penduduk Indonesia Tahun 2015-2045, jumlah penduduk di Pulau Jawa pada tahun 2019 semakin padat, mencapai sekitar 150,4 juta jiwa. Hal ini menyebabkan masalah kesehatan yang muncul juga akan semakin banyak, sehingga perlu dilakukan upaya pengendalian perkembangan penduduk di Pulau Jawa.$^{18}$ Berdasarkan data SDKI prevalensi pemakaian alat/cara KB modern 
pada wanita kawin usia remaja di Pulau Jawa tahun 2017 tergolong masih rendah, yakni 27,8\%.

Kurangnya pengetahuan remaja mengenai metode kontrasepsi dan rendahnya angka pemakaian kontrasepsi modern masih menjadi isu strategis yang harus diselesaikan di Indonesia. Peningkatan kualitas dan cakupan informasi serta peningkatan akses pelayanan kontrasepsi pada wanita kawin usia remaja menjadi kebutuhan sekaligus tantangan program KB saat ini. ${ }^{19}$ Studi ini memiliki tujuann untuk mengetahui hubungan antara tingkat pengetahuan tentang alat/ cara KB dengan pemakaian kontrasepsi modern pada wanita kawin usia remaja di Pulau Jawa dengan menggunakan data SDKI 2017 sehingga diharapkan dapat memberikan masukan dalam upaya membantu meningkatkan kualitas, cakupan informasi serta pelayanan kontrasepsi sebagai strategi intervensi program kesehatan reproduksi yang tepat terutama bagi wanita kawin usia remaja khususnya di Pulau Jawa.

\section{Metode}

Penelitian ini menggunakan data sekunder dari hasil Survei Demografi dan Kesehatan Indonesia (SDKI) Tahun 2017. SDKI 2017 dilaksanakan oleh Badan Pusat Statistik (BPS), Badan Kependudukan dan Keluarga Berencana Nasional (BKKBN), serta Kementerian Kesehatan (Kemenkes) yang bertujuan untuk menyediakan estimasi terbaru yang dapat digunakan sebagai indikator dasar demografi dan kesehatan di Indonesia. ${ }^{20}$ Sampel SDKI 2017 terdiri atas 1.970 blok sensus yang meliputi wilayah perkotaan dan perdesaan dengan kerangka sampel menggunakan Master Sampel Blok Sensus dari hasil Sensus Penduduk 2010 (SP2010) dengan teknik pengambilan sampel yakni sampling dua tahap berstrata. ${ }^{20}$ Kuesioner yang digunakan dalam penelitian ini yakni menggunakan kuesioner SDKI untuk rumah tangga dan kuesioner wanita usia subur (WUS) umur 15-49 yang mengacu pada kuesioner DHS (Demographic Health Surveys) Phase 7 tahun 2015 yang sudah mengakomodasi beberapa isu terbaru sesuai keterbandingan internasional. ${ }^{20}$

Pada data SDKI 2017, terdapat 47.963 rumah tangga dan 49.627 wanita yang diwawancarai hingga selesai dengan tingkat respon sebesar $97,8 \% .{ }^{20}$ Populasi sumber pada penelitian ini adalah seluruh wanita kawin usia 15-19 tahun yang berdomisili di Pulau Jawa pada saat penelitian berlangsung dan berhasil diwawancarai pada saat suvei dilaksanakan yang berjumlah 402 orang. Definisi wanita kawin pada SDKI 2017 adalah wanita yang menyatakan sedang dalam status kawin (menikah) atau hidup bersama dengan pasangannya pada saat survey dilaksanakan. ${ }^{20}$
Kemudian, sampel pada penelitian ini diambil dengan cara total sampling yang berasal dari responden wanita usia 15-19 tahun yang berstatus kawin, berdomisili di Pulau Jawa pada saat penelitian berlangsung dan berhasil diwawancarai pada saat suvei dilaksanakan, serta memenuhi kriteria inklusi yakni memiliki data yang lengkap, tidak ada jawaban yang missing serta kriteria eksklusi yaitu berstatus hamil, atau memiliki riwayat pernah dilakukan histerektomi. Dari hasil cleaning data berdasarkan kriteria tersebut, diketahui populasi eligible pada penelitian ini berjumlah 309 orang, terdapat 91 orang responden yang dieksklusikan karena berstatus hamil dan terdapat 2 missing data yaitu pada variabel pengambilan keputusan tentang KB.

Variabel independen utama atau eksposure dalam penelitian ini adalah pengetahuan tentang Alat/ Cara KB yang terdiri atas 1 pertanyaan dengan 13 bagian terkait alat/cara KB dan masing-masing alat/cara diberi skor 1 sehingga total skor adalah 13 dengan minimal skor pengetahuan baik adalah 7 yaitu skor rata-rata alat/Cara KB yag diketahui oleh wanita kawin usia 1519 tahun berdasarkan data SDKI 2017, kemudian dikategorikan menjadi 2, yakni dengan kode 0 jika pengetahuan kurang (skor 0-6), dan kode 1 untuk pengetahuan baik (skor 7-13). Informasi mengenai pengetahuan metode KB dalam SDKI 2017 diperoleh dengan menanyakan pada responden apakah mereka pernah mendengar setidaknya satu jenis alat/cara KB untuk menunda atau menghindari kehamilan, dan apabila responden tidak dapat menjawab secara spontan, pewawancara melakukan probing dengan membacakan penjelasan dari setiap metode KB dan menanyakan apakah responden mengetahui metode KB tersebut. Responden dikategorikan tahu jika menjawab "Ya" dan tidak tahu jika menjawab "Tidak". ${ }^{20}$ Informasi yang dikumpulkan mencakup metode KB modern yang terdiri dari susuk KB, pil, IUD, suntik KB, metode operasi wanita (MOW) atau sterilisasi wanita, metode operasi pria (MOP) atau sterilisasi pria, kondom, metode amenore laktasi (MAL), diafragma dan kontrasepsi darurat serta alat/cara KB tradisional yang terdiri dari sanggama terputus, pantang berkala, dan alat/cara KB tradisional lainnya. ${ }^{20}$

Variabel dependen pada penelitian ini yaitu pemakaian kontrasepsi modern yang juga dikategorikan menjadi 2, yakni dengan kode 0 jike responden tidak memakai kontrasepsi modern dan kode 1 jika responden memakai metode kontrasepsi modern. Variabel independen lainnya sebagai variabel kovariat yang diikutsertakan dalam penelitian antara lain faktor pendorong (predisposising factor) yang terdiri dari usia, pendidikan, pekerjaan, dan status ekonomi, faktor pemungkin (enabling factor) yang terdiri dari keterpaparan terhadap informasi $\mathrm{KB}$, 
daerah tempat tinggal, status migran, dan kepemilikan jaminan kesehatan, serta faktor penguat (reinforcing factor) yang terdiri dari umur suami dan pendidikan suami, lama menikah, paritas, dan pengambilan keputusan tentang KB.

Analisis pada data penelitian ini dilakukan secara komputerisasi dengan menggunakan software (statistical Package for the Social Sciences) SPSS Versi 24 milik laboratorium komputer Fakultas Kesehatan Masyarakat Universitas Indonesia dan dilakukan dalam beberapa tahap yakni analisis univariat untuk memperoleh gambaran ringkas mengenai distribusi frekuensi dari variabel-variabel penelitian serta dilakukan analisis bivariat dengan menggunakan uji Chi Square dengan confidence interval (CI) 95\%. Hubungan asosiasi dinilai menggunakan prevalence ratio (PR) dan analisis multivariat dengan menggunakan analisis $\mathrm{Cox}$ Regression.

Penggunaan data Survei Demografi dan Kesehatan Indonesia (SDKI) Tahun 2017 pada penelitian ini telah mendapatkan persetujuan dari Lembaga BKKBN. Seluruh responden pada penelitian ini telah memberikan persetujuan berupa informed consent untuk diwawancarai sebelum dilakukan pengumpulan data.

\section{Hasil}

Pada penelitian ini analisis data dilakukan terhadap 309 orang wanita kawin usia remaja sebagai populasi eligible. Berdasarkan Tabel 1, dapat terlihat bahwa sebanyak $62,4 \%$ responden memakai alat kontrasepsi modern. Adapun jenis alat/cara kontrasepsi modern terbanyak yang digunakan oleh wanita kawin usia remaja di Pulau Jawa adalah suntik $(47,9 \%)$ dan pil $(10,6 \%)$. Sedangkan jenis metode kontrasepsi jangka panjang (MKJP) seperti susuk KB $(2,7 \%)$ dan IUD $(1,2 \%)$ masih jarang digunakan oleh wanita kawin usia remaja di Pulau Jawa. Berdasarkan data SDKI Tahun 2017, tidak ada responden wanita kawin usia remaja di Pulau Jawa yang menggunakan metode kontrasepsi kondom dan metode amenore laktasi (MAL).

Tabel 1 menunjukan bahwa 43,6\% wanita kawin usia remaja memiliki tingkat pengetahuan alat/ cara KB yang kurang, atau mengetahui paling banyak 6 alat/cara KB, dan 56,4\% memiliki tingkat pengetahuan alat/cara KB yang baik, atau mengetahui setidaknya 7 alat/cara KB atau lebih. Berdasarkan karakteristik sosiodemografi, diketahui sebagian besar wanita kawin usia remaja berusia 18-19 tahun yakni sebanyak $71,8 \%$, bertempat tinggal di desa sebanyak $63,5 \%$, berstatus bukan migran sebanyak $90,4 \%$, memiliki tingkat pendidikan rendah sebanyak $47,9 \%$, memiliki tingkat ekonomi menengah sebanyak $68,1 \%$, dan mayoritas tidak bekerja sebanyak 75,9\%. Jika ditinjau dari faktor lainnya, seperti faktor suami diketahui bahwa mayoritas wanita kawin usia remaja di Pulau Jawa juga memiliki suami yang masih berusia muda ( $\leq 25$ tahun), yakni sebanyak $68,5 \%$ dengan tingkat pendidikan suami rendah sebanyak 47,9\%. Sebagian besar responden juga diketahui telah menikah selama 0-2 tahun yakni sebanyak $82,8 \%$ dan $45,4 \%$ responden belum memiliki anak. Berdasarkan Tabel 1 juga dapat diketahui sebanyak 65,9\% responden mengaku kurang terpapar terhadap informasi KB baik melalui media maupun melalui kontak personal dengan petugas dan sebanyak $49,5 \%$ responden tidak memiliki jaminan kesehatan.

\section{Tabel 1. Distribusi Frekuensi Pemakaian Kontrasepsi Modern, Tingkat Pengetahuan Alat/Cara KB, dan Faktor Lainnya Pada Wanita Kawin Usia Remaja di Pulau Jawa Berdasarkan Data SDKI 2017}

\begin{tabular}{|c|c|c|c|}
\hline & Variabel & Jumlah (n) & Persentase (\%) \\
\hline \multicolumn{4}{|c|}{ Pemakaian Kontrasepsi Modern } \\
\hline- & Tidak Memakai & 116 & 37,6 \\
\hline- & Memakai & 193 & 62,4 \\
\hline \multicolumn{4}{|c|}{ Tingkat Pengetahuan Alat/Cara KB } \\
\hline- & Kurang (0-6 alat/cara KB) & 135 & 43,6 \\
\hline- & Baik (7-13 alat/cara KB) & 174 & 56,4 \\
\hline \multicolumn{4}{|c|}{ Jenis Alat/Cara KB Modern } \\
\hline- & Suntik & 148 & 47,9 \\
\hline - & Pil & 33 & 10,6 \\
\hline- & IUD & 4 & 1,2 \\
\hline - & Susuk KB & 8 & 2,7 \\
\hline- & Kondom & 0 & 0 \\
\hline- & MAL & 0 & 0 \\
\hline \multicolumn{4}{|l|}{ Umur } \\
\hline- & 15-17 Tahun & 87 & 28,2 \\
\hline- & 18-19 Tahun & 222 & 71,8 \\
\hline \multicolumn{4}{|c|}{ Tingkat Pendidikan } \\
\hline- & Rendah (<Tamat SMA) & 148 & 47,9 \\
\hline- & Tinggi (>= Tamat SMA) & 161 & 52,1 \\
\hline \multicolumn{4}{|c|}{ Tingkat Ekonomi } \\
\hline- & Terbawah & 78 & 25,1 \\
\hline- & Menangah & 210 & 68,1 \\
\hline- & Teratas & 21 & 6,8 \\
\hline \multicolumn{4}{|c|}{ Daerah Tempat Tinggal } \\
\hline- & Desa & 196 & 63,5 \\
\hline- & Kota & 113 & 36,5 \\
\hline \multicolumn{4}{|c|}{ Status Pekerjaan } \\
\hline- & Tidak Bekerja & 235 & 75,9 \\
\hline- & Bekerja & 74 & 24,1 \\
\hline \multicolumn{4}{|c|}{ Status Migran } \\
\hline- & Migran & 30 & 9,6 \\
\hline- & Bukan Migran & 279 & 90,4 \\
\hline \multicolumn{4}{|c|}{ Kepemilikan Jaminan Kesehatan } \\
\hline- & Tidak Memiliki & 153 & 49,5 \\
\hline - & Memiliki & 156 & 50,5 \\
\hline \multicolumn{4}{|c|}{ Paritas : } \\
\hline- & Tidak Memiliki Anak & 140 & 45,4 \\
\hline- & 1 anak atau lebih & 169 & 54,6 \\
\hline \multicolumn{4}{|c|}{ Pengambilan Keputusan Tentang KB } \\
\hline- & Suami & 26 & 8,3 \\
\hline - & Sendiri/Bersama & 283 & 91,7 \\
\hline \multicolumn{4}{|c|}{ Umur Suami } \\
\hline- & $<=25$ Tahun & 212 & 68,5 \\
\hline- & 26-34 Tahun & 91 & 29,3 \\
\hline- & $>=35$ Tahun & 7 & 2,2 \\
\hline \multicolumn{4}{|c|}{ Pendidikan Suami } \\
\hline- & Rendah $(<$ Tamat SMA) & 148 & 47,9 \\
\hline- & Tinggi (>= Tamat SMA) & 161 & 52,1 \\
\hline \multicolumn{4}{|c|}{ Lama Menikah } \\
\hline- & $0-2$ Tahun & 256 & 82,8 \\
\hline- & s= 3 Tahun & 53 & 17,2 \\
\hline \multicolumn{4}{|c|}{ Keterpaparan Informasi KB } \\
\hline- & Kurang Terpapar & 204 & 65,9 \\
\hline- & Terpapar & 105 & 34,1 \\
\hline Total & & 309 & 100 \\
\hline
\end{tabular}


Tabel 2 menunjukkan data distribusi jawaban benar pada responden terkait tingkat pengetahuan alat/ cara KB dan keterpaparan responden terhadap media/ sumber informasi KB. Pada penelitian ini diketahui sebagian besar responden mengetahui alat/cara KB suntikan/injeksi yakni sebesar 99,3\%, pil sebesar $98,6 \%$ dan kondom/karet $\mathrm{KB}$ sebesar $88,3 \%$ sedangkan metode KB yang paling jarang diketahui oleh responden adalah metode $\mathrm{KB}$ darurat/emergency sebesar 7,8\%, metode amenorrhea laktasi (MAL) sebesar $10,7 \%$ dan intravrag/diafragma sebesar $12,3 \%$. Berdasarkan keterpaparan terhadap sumber informasi $\mathrm{KB}$, diketahui bahwa sebagian besar responden mendapatkan informasi mengenai KB melalui media televisi $66,2 \%$, billboard/banner $38,8 \%$ dan melalui internet $34,6 \%$. Selain itu jika ditinjau berdasarkan kontak personal dengan petugas, diketahui sebagian besar responden mendapatkan informasi KB melalui bidan/perawat, yaitu sebanyak 40,4\%.

Tabel 2. Distribusi Responden Berdasarkan Jawaban Benar Tingkat Pengetahuan Alat/Cara KB dan Keterpaparan Media/Sumber Informasi KB Pada Wanita Kawin Usia Remaja di Pulau Jawa

\begin{tabular}{|c|c|c|}
\hline \multirow[t]{2}{*}{ Variabel } & \multicolumn{2}{|c|}{ Jumlah } \\
\hline & $\mathbf{N}$ & $\%$ \\
\hline \multicolumn{3}{|l|}{ Tingkat Pengetahuan } \\
\hline Pernah mendengar alat/cara KB metode pil & 305 & 98,6 \\
\hline Pernah mendengar alat/cara KB metode & 213 & 68,9 \\
\hline IUD/AKDR/Spiral & & \\
\hline $\begin{array}{l}\text { Pernah mendengar alat/cara KB metode } \\
\text { suntikan/injeksi }\end{array}$ & 307 & 99,3 \\
\hline $\begin{array}{l}\text { Pernah mendengar alat/cara KB metode } \\
\text { intravrag/diafragma }\end{array}$ & 38 & 12,3 \\
\hline $\begin{array}{l}\text { Pernah mendengar alat/cara KB metode } \\
\text { kondom/karet KB }\end{array}$ & 273 & 88,3 \\
\hline $\begin{array}{l}\text { Pernah mendengar alat/cara KB metode sterilisasi } \\
\text { wanita/Tubektomi/MOW }\end{array}$ & 167 & 54,0 \\
\hline $\begin{array}{l}\text { Pernah mendengar alat/cara KB metode sterilisasi } \\
\text { pria/Vasektomi/MOP }\end{array}$ & 76 & 24,7 \\
\hline $\begin{array}{l}\text { Pernah mendengar alat/cara KB metode pantang } \\
\text { berkala/kalender }\end{array}$ & 97 & 31,3 \\
\hline $\begin{array}{l}\text { Pernah mendengar alat/cara KB metode senggama } \\
\text { terputus }\end{array}$ & 110 & 35,3 \\
\hline $\begin{array}{l}\text { Pernah mendengar alat/cara KB metode susuk } \\
\text { KB/Implan }\end{array}$ & 261 & 84,4 \\
\hline $\begin{array}{l}\text { Pernah mendengar alat/cara KB metode } \\
\text { amenorrhea laktasi (MAL) }\end{array}$ & 33 & 10,7 \\
\hline $\begin{array}{l}\text { Pernah mendengar alat/cara KB metode kontrasepsi } \\
\text { darurat/Emergency }\end{array}$ & 24 & 7,8 \\
\hline \multicolumn{3}{|l|}{ Sumber Informasi KB } \\
\hline Poster/Pamflet/Leaflet & 118 & 38 \\
\hline Billboad/Banner/Spanduk/Umbul-Umbul/Mural & 120 & 38,8 \\
\hline Televisi & 205 & 66,2 \\
\hline Koran/Majalah & 38 & 12,2 \\
\hline Radio & 37 & 11,8 \\
\hline Internet & 107 & 34,6 \\
\hline Petugas Lapangan KB & 27 & 8,7 \\
\hline Guru & 7 & 2,4 \\
\hline Tokoh Agama & 10 & 3,3 \\
\hline Dokter & 32 & 10,2 \\
\hline Bidan/Perawat & 125 & 40,4 \\
\hline Pemimpin Desa/Tokoh Masyarakat & 0 & 0 \\
\hline PKK/Kader & 31 & 10,1 \\
\hline Apoteker & 5 & 1,7 \\
\hline Mobil Unit Penerangan KB & 1 & 0,5 \\
\hline Kesenian & 1 & 0,5 \\
\hline
\end{tabular}

Hasil analisis bivariat yang dilakukan pada penelitian ini disajikan pada Tabel 3. Berdasarkan dari hasil uji chi-square, diketahui terdapat perbedaan perilaku pemakaian kontrasepsi modern pada responden dengan tingkat pengetahuan tentang alat/ cara KB baik dengan tingkat pengetahuan tentang alat/ cara KB kurang ( $p$ value $=0,03$ ). Hubungan antara tingkat pengetahuan tentang alat/cara KB dengan pemakaian kontrasepsi modern pada wanita kawin usia remaja ini memiliki nilai asosiasi PR sebesar 0,71 (CI 95\% 0,52-0,96). Artinya, responden yang memiliki tingkat pengetahuan yang kurang, memiliki perilaku tidak memakai kontrasepsi modern 0,71 kali lebih rendah dibandingkan dengan yang memiliki tingkat pengetahuan yang baik, atau responden yang memiliki tingkat pengetahuan kurang 1,4 kali lebih berpeluang untuk memiliki perilaku memakai kontrasepsi modern dibandingkan dengan yang memiliki tingkat pengetahuan yang baik. Hasil ini menunjukkan bahwa proporsi pemakaian kontrasepsi modern lebih rendah pada wanita kawin usia remaja dengan tingkat pengetahuan baik dibandingkan remaja dengan tingkat pengetahuan kurang.

Berdasarkan hasil analisis bivariat terhadap faktor lainnya, Tabel 3 memperlihatkan terdapat hubungan signifikan antara paritas dan kepemilikan jaminan kesehatan dengan pemakaian kontrasepsi modern pada wanita kawin usia remaja di Pulau Jawa. Sedangkan variabel lainnya (umur, tingkat pendidikan, tingkat ekonomi, daerah tempat tinggal, status pekerjaan, status migran, pengambilan keputusan tentang KB, umur suami, pendidikan suami, lama menikah dan keterpaparan terhadap informasi KB) tidak menunjukkan hubungan yang signifikan terhadap pemakaian kontrasepsi modern.

Hasil dari analisis multivariat pada penelitian ini disajikan pada Tabel 4. Agar diperoleh model multivariat yang hemat dan mampu menjelaskan variabel independen dan variabel dependen, dilakukan prosedur pemilihan variabel dari hasil analisis bivariat. Jika hasil uji statistik bivariat memiliki nilai $\mathrm{p}<0,25$ maka variabel tersebut dapat masuk pada model multivariat, namun jika nilai $p>0,25$ maka variabel tersebut tidak dimasukkan kedalam analisis multivariat. Pada penelitian ini variabel yang masuk kedalam analisis model multivariat adalah variabel tingkat pengetahuan, tingkat pendidikan, kepemilikan jaminan kesehatan, paritas, pengambilan keputusan tentang KB, pendidikan suami, dan lama menikah/ hidup bersama. Pada hasil analisis diketahui dari semua variabel yang potensial sebagai confounder, hanya terdapat 1 variabel yang menunjukkan hasil sebagai confounder pada model akhir, yakni paritas. Model akhir analisis multivariat hubungan antara tingkat 
Tabel 3. Hasil Analisis Hubungan Tingkat Pengetahuan Alat/Cara KB dan Faktor Lainnya dengan Pemakaian Kontrasepsi Modern Pada Wanita Kawin Usia Remaja di Pulau Jawa Berdasarkan Data SDKI 2017

\begin{tabular}{|c|c|c|c|c|c|c|c|c|}
\hline \multirow[t]{3}{*}{ Variabel } & \multicolumn{4}{|c|}{ Pemakaian KB Modern } & \multicolumn{2}{|c|}{ Total } & \multirow{3}{*}{$\begin{array}{l}\text { PR Crude } \\
\text { (95\% CI) }\end{array}$} & \multirow[t]{3}{*}{ p value } \\
\hline & \multicolumn{2}{|c|}{ Tidak } & \multicolumn{2}{|c|}{ Ya } & \multirow[b]{2}{*}{$\mathbf{n}$} & \multirow[b]{2}{*}{$\%$} & & \\
\hline & $\mathbf{N}$ & $\%$ & $\mathbf{N}$ & $\%$ & & & & \\
\hline \multicolumn{9}{|c|}{ Tingkat Pengetahuan Alat/Cara KB } \\
\hline $\begin{array}{l}\text { Kurang } \\
(0-6 \text { alat/cara KB) }\end{array}$ & 41 & 30,4 & 94 & 69,6 & 135 & 100 & $\begin{array}{c}0,71 \\
(0,52-0,96)\end{array}$ & $0,03^{*}$ \\
\hline $\begin{array}{l}\text { Baik } \\
\text { (7-13 alat/caraKB) }\end{array}$ & 75 & 43,1 & 99 & 56,9 & 174 & 100 & Reference & \\
\hline \multicolumn{9}{|l|}{ Umur } \\
\hline 15-17 Tahun & 36 & 40,9 & 52 & 59,1 & 88 & 100 & $\begin{array}{c}1,12 \\
(0,83-1,52)\end{array}$ & 0,55 \\
\hline 18-19 Tahun & 81 & 36,5 & 141 & 63,5 & 222 & 100 & Reference & \\
\hline \multicolumn{9}{|l|}{ Tingkat Pendidikan } \\
\hline Rendah $(<$ Tamat SMA $)$ & 47 & 31,8 & 101 & 68,2 & 148 & 100 & $\begin{array}{c}0,741 \\
(0,55-0,99)\end{array}$ & 0,06 \\
\hline $\begin{array}{l}\text { Tinggi } \\
(>=\text { Tamat SMA })\end{array}$ & 69 & 42,9 & 92 & 57,1 & 161 & 100 & Reference & \\
\hline \multicolumn{9}{|l|}{ Tingkat Ekonomi } \\
\hline Terbawah & 26 & 33,8 & 51 & 66,2 & 77 & 100 & $\begin{array}{c}1,35 \\
(0,37-4,92)\end{array}$ & 0,645 \\
\hline Menengah & 86 & 40,8 & 125 & 59,2 & 211 & 100 & $\begin{array}{c}1,75 \\
(0,54-5,63)\end{array}$ & 0,349 \\
\hline Teratas & 4 & 19,0 & 17 & 81 & 21 & 100 & Reference & \\
\hline \multicolumn{9}{|l|}{ Daerah Tempat Tinggal } \\
\hline Desa & 74 & 37,8 & 122 & 62,2 & 196 & 100 & $\begin{array}{c}1,02 \\
(0,75-1,37)\end{array}$ & 1.000 \\
\hline Kota & 42 & 37,2 & 71 & 62,8 & 113 & 100 & Reference & \\
\hline \multicolumn{9}{|l|}{ Status Pekerjaan } \\
\hline Tidak Bekerja & 87 & 37,0 & 148 & 63,0 & 235 & 100 & $\begin{array}{c}0,93 \\
(0,67-1,28)\end{array}$ & 0,644 \\
\hline Bekerja & 30 & 40,0 & 45 & 60,0 & 75 & 100 & Reference & \\
\hline \multicolumn{9}{|l|}{ Status Migran } \\
\hline Migran & 14 & 46,7 & 16 & 53,3 & 30 & 100 & $\begin{array}{c}1,28 \\
(0,85-1,93)\end{array}$ & 0,375 \\
\hline Bukan Migran & 102 & 36,6 & 177 & 63,4 & 279 & 100 & Reference & \\
\hline \multicolumn{9}{|c|}{ Kepemilikan Jaminan Kesehatan } \\
\hline Tidak Memiliki & 48 & 31,4 & 105 & 68,6 & 153 & 100 & $\begin{array}{c}0,71 \\
(0,53-0,95)\end{array}$ & $0,03^{*}$ \\
\hline Memiliki & 69 & 44,2 & 87 & 55,8 & 156 & 100 & Reference & \\
\hline \multicolumn{9}{|l|}{ Paritas } \\
\hline Tidak Memiliki Anak & 83 & 58,9 & 58 & 41,1 & 141 & 100 & $\begin{array}{c}2,93 \\
(2,10-4,07)\end{array}$ & $0,000^{*}$ \\
\hline 1 Anak/lebih & 34 & 20,1 & 135 & 79,9 & 169 & 100 & Reference & \\
\hline \multicolumn{9}{|c|}{ Pengambilan Keputusan Tentang KB } \\
\hline Suami & 14 & 53,8 & 12 & 46,2 & 26 & 100 & $\begin{array}{c}1,49 \\
(1,01-2,19)\end{array}$ & 0,119 \\
\hline Sendiri/Bersama & 103 & 36,3 & 181 & 63,7 & 284 & 100 & Reference & \\
\hline \multicolumn{9}{|l|}{ Umur Suami } \\
\hline$<=25$ Tahun & 88 & 41,7 & 123 & 58,3 & 211 & 100 & $\begin{array}{c}1,67 \\
(0,23-12,13)\end{array}$ & 0,612 \\
\hline 26-34 Tahun & 26 & 28,9 & 64 & 71,1 & 90 & 100 & $\begin{array}{c}1,11 \\
(0,15-8,46)\end{array}$ & 0,922 \\
\hline$>=35$ Tahun & 1 & 16,7 & 5 & 83,3 & 6 & 100 & Reference & \\
\hline \multicolumn{9}{|l|}{ Pendidikan Suami } \\
\hline Rendah $(<$ Tamat SMA) & 35 & 30,4 & 80 & 69,6 & 115 & 100 & $\begin{array}{c}0,73 \\
(0,53-1,07)\end{array}$ & 0,06 \\
\hline $\begin{array}{l}\text { Tinggi } \\
(>=\text { Tamat SMA) }\end{array}$ & 81 & 41,8 & 113 & 58,2 & 194 & 100 & Reference & \\
\hline Lama Menikah/Hidup & rsame & & & & & & & \\
\hline 0-2 Tahun & 101 & 39,5 & 155 & 60,5 & 256 & 100 & $\begin{array}{c}1,39 \\
(0,89-2,20)\end{array}$ & 0,171 \\
\hline$>=3$ Tahun & 15 & 28,3 & 38 & 71,7 & 53 & 100 & Reference & \\
\hline Keterpaparan Informa & & & & & & & & \\
\hline Kurang Terpapar & 76 & 37,3 & 128 & 62,7 & 204 & 100 & $\begin{array}{c}0,98 \\
(0,72-1,32)\end{array}$ & 0,984 \\
\hline Terpapar & 40 & 38,1 & 65 & 61,9 & 105 & 100 & Reference & \\
\hline
\end{tabular}

pengetahuan tentang alat/cara KB dengan pemakaian kontrasepsi modern pada wanita kawin usia remaja di Pulau jawa menjelaskan bahwa tingkat pengetahuan tentang alat/cara KB tidak memiliki hubungan dengan pemakaian kontrasepsi modern pada wanita kawin usia remaja di Pulau Jawa setelah dikontrol oleh faktor paritas, pendidikan suami, keputusan $\mathrm{KB}$, dan kepemilikan jaminan kesehatan (PR = 0,75; CI 95\% 
$0,42-1,36)$. Artinya, responden yang memiliki tingkat pengetahuan yang kurang, memiliki perilaku tidak memakai kontrasepsi modern 0,75 kali lebih rendah dibandingkan dengan yang memiliki tingkat pengetahuan tentang alat/cara KB yang baik.

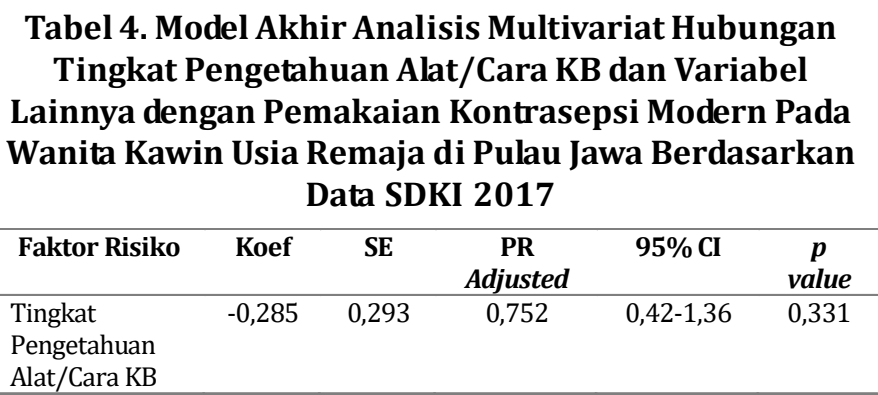

Adjusted berdasarkan paritas, pendidikan suami, keputusan KB, dan kepemilikan jaminan kesehatan

\section{Pembahasan}

Hasil analisis univariat pada penelitian ini memperlihatkan proporsi pemakaian kontrasepsi modern pada wanita kawin usia remaja sebanyak 62,4\%. Berdasarkan Renstra BKKBN 2020-2024 angka ini masih dibawah target capaian modern Contraceptive Prevalence Rate (mCPR) yakni 63,41\%. ${ }^{4}$ Namun hasil ini menunjukkan angka yang lebih tinggi jika dibandingkan dengan penelitian yang dilakukan oleh Zhihui Li, et al tahun 2020 di 103 negara berpenghasilan rendah dan menengah di dunia yang pada hasilnya ditemukan bahwa rata-rata pemakaian kontrasepsi modern pada wanita kawin usia remaja di daerah Asia Tenggara adalah sebesar 44,9\%. ${ }^{21}$ Sementara itu, berdasarkan analisis data Riskesdas 2013 yang dilakukan oleh Rizkianti A, dkk diketahui pemakaian kontrasepsi modern pada remaja perempuan kawin di Indonesia berkisar sekitar $54,2 \%{ }^{22}$

Jenis kontrasepsi modern terbanyak yang dipakai oleh wanita kawin usia remaja di Indonesia masih didominasi oleh metode jangka pendek terutama pil dan suntik. BKKBN menyebutkan $>50 \%$ pengguna kontrasepsi membatasi kelahiran dengan metode jangka pendek. Hal ini karena metode tersebut dianggap lebih cepat dan praktis, murah, dan mudah jika ingin menghentikan pemakaian tanpa harus menghubungi petugas kesehatan. ${ }^{23,24}$ Sedangkan metode kontrasepsi jangka panjang (MKJP) seperti susuk KB dan IUD masih jarang digunakan oleh wanita kawin usia remaja di Indonesia. Hal ini berkaitan dengan kekhawatiran akibat adanya kesalahpahaman mengenai efek samping penggunaan dan pengaruh metode tersebut terhadap kesehatan secara umum. ${ }^{23}$

Hasil penelitan ini menunjukan bahwa 43,6\% wanita kawin usia remaja memiliki tingkat pengetahuan alat/cara KB yang kurang, atau mengetahui paling banyak 6 alat KB, dan 56,4\% memiliki tingkat pengetahuan alat/cara KB yang baik, atau mengetahui setidaknya 7 alat/cara KB atau lebih. Dasar pengelompokkan tingkat pengetahuan pada studi ini berdasarkan skor rata-rata alat KB yang diketahui oleh wanita kawin usia 15-19 tahun dari data SDKI 2017, yakni 7 alat/cara KB. Definisi yang digunakan untuk mengukur tingkat pengetahuan pada Kuesioner SDKI hanya mencakup pertanyaan sederhana mengenai jenis-jenis alat/cara KB tersebut. Hasil ini berbeda dengan penelitian lain yang dilakukan Aryanti di Aikmel, Lombok Timur yang menyebutkan terdapat 92,9\% wanita kawin usia dini dengan tingkat pengetahuan kurang. Pada penelitian tersebut tingkat pengetahuan diukur dengan menggunakan kuesioner yang mencakup pengertian $\mathrm{KB}$, jenis metode $\mathrm{KB}$, efek samping metode $\mathrm{KB}$, dan pengetahuan mengenai tempat mendapatkan pelayanan kontrasepsi. ${ }^{16}$

Pada penelitian ini diketahui 99,3\%, responden mengetahui alat/cara KB suntikan/injeksi, pil sebesar 98,6\% responden, dan kondom/karet KB sebesar $88,3 \%$ responden. Hasil ini juga didapatkan melalui pertanyaan yang sama mengenai apakah responden pernah mendengar mengenai jenis metode KB tersebut, dan apabila responden tidak mampu memberikan jawaban spontan, petugas wawancara melakukan probing dengan membacakan penjelasan dari setiap metode $\mathrm{KB}$ dan menanyakan apakah responden mengetahui metode KB tersebut. Hasil ini kurang dapat menggambarkan tingkat pengetahuan responden secara keseluruhan. Penelitian lain yang dilakukan oleh Thapa P di Kota Dharan, Nepal menemukan bahwa walaupun $91 \%$ responden mengetahui alat/cara KB pil, namun hanya $68,4 \%$ yang mengetahui cara mengkonsumsi pil dengan benar. ${ }^{17}$ Walaupun mayoritas responden pernah mendengar berbagai alat/ cara KB, namun pengetahan mengenai metode tersebut secara lebih spesifik masih sangat kurang. ${ }^{17}$

Hasil analisis multivariat pada penelitian ini menemukan bahwa tidak ada hubungan yang signifikan antara tingkat pengetahuan tentang alat/cara KB dengan pemakaian kontrasepsi modern pada wanita kawin usia remaja di Pulau Jawa setelah dikontrol oleh faktor paritas, pendidikan suami, keputusan $\mathrm{KB}$, dan kepemilikan jaminan kesehatan ( $\mathrm{PR}=0,75$; CI 95\% $0,42-1,36)$. Penelitian ini tidak menunjukkan hasilyang konsisten dengan penelitian sebelumnya, yang dilakukan oleh Goncalves, dkk yang menemukan tingkat pengetahuan mengenai alat/cara KB mempengaruhi pilihan seseorang untuk memakai alat kontrasepsi dengan nilai asosiasi yang positif $(\mathrm{PR}=1,54$; $\mathrm{p}=0,006) .{ }^{25}$ Penelitian lain yang dilakukan oleh Rocca \& Harper di Amerika Serikat juga menyatakan bahwa pengetahuan merupakan faktor risiko yang 
mempengaruhi pemakaian kontrasepsi pada remaja $\left(\mathrm{OR}=3,86\right.$; CI 95\% 2,08-7,15).$^{26}$ Perbedaan hasil ini dengan penelitian sebelumnya kemungkinan adalah akibat adanya bias informasi karena kurang tereskplorenya pertanyaan yang digunakan untuk mengukur tingkat pengetahuan mengenai alat/cara KB pada kuesioner SDKI yang dapat membuat responden kurang terbuka dalam menjawab pertanyaan sehingga dapat menghasilkan nilai yang underestimate atau overestimate. Selain itu kemungkinan bias informasi juga dapat terjadi karena pengkategorian yang dilakukan (pemilihan cut-off yang kurang tepat) sehingga dapat menyebabkan nilai asosiasi yang underestimate atau overestimate. Namun karena pengkategorian pada penelitian ini tidak dibedakan antara kedua kelompok, maka bias yang terjadi kemungkinan bersifat non-differential. Adanya kemungkinan faktor risiko lain yang belum dimasukkan dalam penelitian ini juga dapat mempengaruhi hasil tersebut, salah satunya adalah faktor budaya. Hal ini juga dikemukakan oleh Ahmad $S$, dkk bahwa adanya kemungkinan faktor lain yang lebih berpengaruh terhadap pemakaian kontrasepsi modern di Indonesia, salah satunya yaitu faktor keberagaman budaya, seperti budaya banyak anak banyak rejeki atau kepercayaan anak dengan jenis kelamin tertentu lebih bernilai sehingga menyebabkan suatu pasangan berkeinginan untuk menambah anak. ${ }^{27}$ Namun pada data SDKI faktor tersebut tidak diukur.

Menurut Notoadmodjo, pengetahuan terbagi atas 6 bagian, yakni tahu (know), memahami (comprehension), aplikasi (application), analisis (analysis), sintesa (synthesis) serta evaluasi (evaluation).$^{28}$ Jika ditinjau pertanyaan dari Kuesioner SDKI hanya mencakup komponen paling dasar dari pengetahuan, yaitu tahu (know), yang mengukur kemampuan mengingat suatu materi yang pernah dipelajari. Hal ini terlihat dari pertanyaan yang diberikan pada kuesioner SDKI, responden hanya ditanya secara spontan apakah mereka pernah mendengar setidaknya satu jenis metode KB untuk menunda atau menghindari kehamilan, dan apabila responden tidak dapat menjawab, pewawancara melakukan probing dengan membacakan penjelasan dari setiap alat/cara KB yang sudah tertera pada kuesioner dan menanyakan kembali apakah responden mengetahui alat/cara KB tersebut. Pertanyaan komponen pengetahuan mengenai alat/cara KB pada kuesioner SDKI kurang tereksplore terhadap komponen pengetahuan lainnya seperti komponen pemahaman (comprehension) yang mencakup kemampuan menjelaskan secara benar dan menginterpretasi komponen secara rinci, misalnya pengetahuan mengenai cara kerja dan efek samping dari masing-masing alat/cara KB tersebut, kemudian komponen aplikasi (application) yang mencakup kemampuan menjelaskan bagaimana cara menggunakan materi pada kondisi yang sebenarnya sesuai dengan prinsip penggunaannya, dalam hal ini yaitu pengetahuan mengenai prinsip/cara pemakaian masing-masing alat/cara KB, dan sebagainya. ${ }^{28}$

Beberapa penelitian yang dilakukan di negara maju seperti Amerika Serikat, Australia dan Jerman diketahui telah menggunakan kuesioner dengan komponen pertanyaan yang lebih lengkap untuk mengukur tingkat pengetahauan mengenai alat/cara KB pada responden remaja. Contohnya di Amerika Serikat, penelitian yang dilakukan oleh Craig $A D$, et al untuk mengeksplore tingkat pengetahuan dan sikap remaja terkait kontrasepsi, peneliti menggunakan kuesioner terstandar dari National Survey of Reproductive and Contraceptive Knowlegde yang pertanyaanya tidak hanya mencakup mengenai jenis alat/cara KB yang diketahui, namun juga mengenai efek samping, cara pakai dan efektifitas dari masing-masing jenis alat/cara KB tersebut ${ }^{29}$ Begitu pula pada proyek penelitian TANCO (Thinking About Needs in Contraception) pada remaja di Jerman, kuesioner yang digunakan pada responden juga mencakup pertanyaan yang lebih rinci mengenai jenis-jenis alat/cara KB, efek samping, cara pakai dan cara kerja dari masing-masing alat/cara KB. ${ }^{30}$

Dalam mengambil keputusan untuk menerima sesuatu, diperlukan 4 tahap yaitu tahap pengetahuan (knowledge), tahap persuasi (persuasion), tahap pengambilan keputusan (decision) dan tahap konfirmasi (confirmation). ${ }^{31}$ WHO menemukan bahwa teori kognitif sosial merupakan metode yang dianggap paling berhasil sebagai upaya peningkatan intervensi program kontrasepsi bagi remaja. ${ }^{32}$ Teori ini mengungkapkan bahwa seseorang dapat belajar mengadopsi perilaku baru apabila diperkuat dengan pengetahuan mengenai risiko dan manfaat dari perubahan perilaku, dalam hal ini bukan hanya mengenai jenis alat/cara KB, namun juga mengenai tujuan, cara pakai dan efek samping. Selain itu juga diperlukan pengembangan motivasi diri untuk dapat mengubah perilaku, dan penilaian ekspektasi manfaat dari perubahan perilaku. ${ }^{32}$

Sejumlah keterbatasan ditemukan dalam penelitian ini. Pada penelitian ini tidak melibatkan remaja wanita usia 15-19 tahun yang berstatus tidak kawin sehingga hasilnya tidak dapat digeneralisasi terhadap seluruh remaja wanita usia 15-19 tahun. Selain itu jawaban yang diberikan oleh responden bersifat self-reporting, sehingga kemungkinan terjadinya bias informasi tidak dapat dihindari. Desain penelitian yang digunakan pada penelitian ini adalah 
cross sectional sehingga asosiasi yang tergambar pada penelitian ini kurang dapat menggambarkan adanya hubungan kausalitas. Kemudian komponen pertanyaan mengenai tingkat pengetahuan pada Kuesioner SDKI 2017 terbatas hanya mengenai jenisjenis alat/cara KB, belum ditanyakan lebih detail mengenai efek samping, cara pakai, dan lain-lain dari masing-masing alat/cara sehingga komponen variabel tingkat pengetahuan pada penelitian ini dinilai belum sempurna.

\section{Kesimpulan}

Berdasarkan pembahasan sebelumnya, terdapat kemungkinan adanya bias informasi non differential pada data SDKI 2017 yang dapat mempengaruhi hasil asosiasi akhir secara keseluruhan. Penelitian ini menyimpulkan berdasarkan data SDKI 2017 tidak terdapat hubungan antara tingkat pengetahuan mengenai alat/cara KB dengan pemakaian kontrasepsi modern pada wanita kawin usia remaja di Pulau Jawa. Studi ini merekomendasikan untuk dilakukan perbaikan pada pengukuran variabel pengetahuan pada survei selanjutnya dengan menggunakan definisi yang lebih spesifik sehingga dapat menggambarkan tingkat pendidikan responden dengan lebih akurat.

\section{Ucapan Terima Kasih}

Penelitian ini dapat dilaksanakan dengan baik berkat dukungan dan bantuan dari berbagai pihak. Penulis mengucapkan terima kasih kepada pemilik data SDKI yaitu Lembaga BKKBN, Lembaga Pengelola Dana Pendidikan (LPDP) selaku pemberi dukungan finansial melalui Beasiswa Pendidikan Indonesia, dan kepada dosen Fakultas Kesehatan Masyarakat Universitas Indonesia.

\section{Daftar Pustaka}

1. Casey SE, Gallagher MC, Kakesa J, et al. Contraceptive use among adolescent and young women in North and South Kivu, Democratic Republic of the Congo: A cross-sectional population-based survey. PLoS Med. 2020;17(3). doi:10.1371/JOURNAL.PMED.1003086

2. Appiah F, Seidu AA, Ahinkorah BO, Baatiema L, Ameyaw EK. Trends and determinants of contraceptive use among female adolescents in Ghana: Analysis of 2003-2014 Demographic and Health Surveys. SSM - Popul Heal. 2020;10:100554.

3. WHO. Preventing Early Pregnancy And Poor Reproductive Outcomes Among Adolescents In Developing Countries: What The Evidence Says. Published online 2011:1-8.

4. BKKBN. Rencana Strategis BKKBN 2020-2024. Published online 2020:1-71.
5. BKKBN. Laporan Kinerja 2019. Otoritas Jasa Keuang. Published online 2019:1-50. https://www.ojk.go.id/id/datadan-statistik/laporan-kinerja/Pages/-Laporan-Kinerja-OJK2019.aspx

6. Morris JL, Rushwan H. Adolescent sexual and reproductive health: The global challenges. Int J Gynecol Obstet. 2015;131:S40-S42. doi:10.1016/j.ijgo.2015.02.006

7. Chandra-Mouli V, McCarraher DR, Williamson NE. Identifying and overcoming barriers that adolescents in low and middle income $\urcorner$ countries face in obtaining and using contraception. Entre Nous Eur Mag Sex Reprod Heal. 2013;79(79):10-11. http://www.euro.who.int/_data/ assets/pdf_file/0004/237199/Entre-Nous-79-Eng.pdf

8. Leftwich HK, Alves MVO. Adolescent Pregnancy. Pediatr Clin North Am. 2017;64(2):381-388.

9. Eisenberg DL, Secura GM, Madden TE, Allsworth JE, Zhao Q Peipert JF. Knowledge of contraceptive effectiveness. Am JObstet Gynecol. 2012;206(6):479.e1-479.e9. doi:10.1016/ j.ajog.2012.04.012

10. MA T, BA A. Knowledge and Use of Contraceptives among Female Adolescents in Selected Senior Secondary Schools in Ife Central Local Government of Osun State. J Community Med Health Educ. 2018;08(03):1647-1661.

11. Ritter T, Dore A, McGeechan K. Contraceptive knowledge and attitudes among 14-24-year-olds in New South Wales, Australia. Aust N ZJ Public Health. 2015;39(3):267-269.

12. WHO. Global Consensus Statement for Expanding Contraceptive Choice for Adolescents and Youth To Include Long-Acting Reversible Contraception. Published online 2015:1-5.

13. Solikhah S, Nurdjannah S. Knowledge and Behaviour about Adolescent Reproductive Health in Yogyakarta, Indonesia. Int J Public Heal Sci. 2015;4(4):326.

14. Raidoo S, Kaneshiro B. Providing Contraception to Adolescents. Obstet Gynecol Clin North Am. 2015;42(4):631645.

15. Frost JJ, Lindberg LD, Finer LB. Young Adults' Contraceptive Knowledge, Norms and Attitudes: Associations with Risk Of Unintended Pregnancy. Perspect Sex Reprod Health. 2012;44(2):107-116.

16. Aryanti H. Faktor-Faktor Yang Berhubungan Dengan Penggunaan Kontrasepsi Pada Wanita Kawin Usia Dini Di Kecamatan Aikmel, Kabupaten Lombok Timur. Vol 2.; 2014.

17. Thapa P, Pokharel N, Shrestha M. Knowledge, Attitude and Practices of Contraception among the Married Women of Reproductive Age Group in Selected Wards of Dharan SubMetropolitan City.J Contracept Stud. 2018;03(03):1-8.

18. Beenackers MA, Oude Groeniger J, Kamphuis CBM, Van Lenthe FJ. Urban population density and mortality in a compact Dutch city: 23-year follow-up of the Dutch GLOBE study. Heal Place. 2018;53(June):79-85.

19. Wahyuni T. Faktor-Faktor Penggunaan Kontrasepsi Pada Wanita Usia Subur 15-19 Tahun Di Indonesia ( Data Srpjmn 2017 ). JJKFT Univ Muhammadiyah Tangerang. 2019;4(1). 20. BKKBN. Survei Demografi Dan Kesehatan Indonesia 2017.; 2017. http://www.dhsprogram.com.

21. Li Z, Patton G, Sabet F, Zhou Z, Subramanian S V., Lu C. Contraceptive Use in Adolescent Girls and Adult Women in Low- and Middle-Income Countries. JAMA Netw open. 2020;3(2):e1921437. 
22. Rizkianti A, Amaliah N, Rachmalina R. Penggunaan Kontrasepsi pada Remaja Perempuan Kawin di Indonesia (Analisis Riskesdas 2013). Bul Penelit Kesehat. 2017;45(4):257-266.

23. Skata. Pilihan Metode Kontrasepsi Bagi Masyarakat Umum: Panduan Untuk Petugas Dan Kader Lapangan. Vol 11.; 2017.

24. Tibaijuka L, Odongo R, Welikhe E, et al. Factors influencing use of long-acting versus short-acting contraceptive methods among reproductive-age women in a resource-limited setting. BMC Womens Health. 2017;17(1).

25. Gonçalves MJ, Suariyani NLP, Suryadhi NT. Hubungan Pengetahuan dan Sikap dengan Pemakaian Alat Kontrasepsi pada PUS di Puskesmas Comoro Dili Timor Leste. Public Heal Prev Med Arch. 2014;2(1):39.

26. Rocca CH, Harper CC. Do Racial and Ethnic Differences in Contraceptive Attitudes and Knowledge Explain Disparities In Method Use? Perspect Sex Reprod Health. 2012;44(3):150158.
27. Sulfanawati Ahmad, Hutagaol Ester MR. Hubungan Pengetahuan Ibu Usia Remaja Dan Dewasa Muda Tentang Kb Dengan Penggunaan Alat Kontrasepsi Setelah Melahirkan Di Puskesmas Mabapura Kabupaten Halmahera Timur. J Keperawatan Unsrat. 2014;2(2):1689-1699.

28. Seokidjo Notoadmodjo. Promosi Kesehatan Dan Perilaku Kesehatan. Edisi Revi. Rineka Cipta; 2017.

29. Amaranta D. Craig, BSa, b, , Christine Dehlendorf, MD, MASa, b, Sonya Borrero, MD, MSc, d, Cynthia C. Harper, PhDb, and Corinne H. Rocca, PhD Mph. Exploring Young Adults' Contraceptive Knowledge and Attitudes: Disparities by Race/ Ethnicity and Age. Womens Heal Issues. 2014;23(1):1-7.

30. Oppelt PG, Fahlbusch C, Heusinger K, Lotz L, Dittrich R, Baier F. Situation of adolescent contraceptive use in Germany. Geburtshilfe Frauenheilkd. 2018;78(10):999-1007.

31. Novianti. Faktor-Faktor Yang Mempengaruhi Pemilihan Jenis Metode Kontrasepsi. 2014;1:212-216.

32. Warriner I. Theory-based interventions for contraception/ : RHL Commentary. World Heal Organ. 2012;(11). 